Kohl: a Journal for Body and Gender Research Vol. 5, No. 2 (Summer 2019)

\title{
The Sterility of Evil
}

Sophie Chamas 
"What is this body, that clings to life? What is this body, that challenges death? Strong, titanic, you were, my mother, and now your body, while starveling, still displays your persistent strength even in the face of the most severe diseases. Oh the pain my eyes feel at the sight of you under the cover of death, quietly lost in pain. I feel my mind and spirit struggling to weep inside my body. I want release for you, for my pain at least to gain respite from the sight of you like this. I will miss your presence, even if limited to this sickly body, free of sensations, for even a glimpse of your shadow brings me tranquility. How hard life is when it confronts you with the most difficult of choices. I want peace for you but I want you to stay. Forgive me mother, I ask for nothing but your rest, you who is my eyes, my pulse, my heart. Rest for you and pain for me until the end of my days, for that is how heavily guilt weighs on my conscience. My mother, my mother, my mother, until my very last breath."

$* * *$

What does it mean to speak of the labor demanded of the dead or dying? My grandmother, my mother tells me, died years ago. The being who lies now in a hospital bed in Beirut's southern suburbs, vacanteyed and gape-mouthed, is a husk. Her soul, she tells me, has long departed - more hope than conviction. Her body is kept alive as it fights to decay. The flesh protests, it resists, marshalling ulcers and rashes, cracking bones, even launching itself into septic shock, but it continues to lose its attempts at a dignified death.

There is money to be made, after all, in forcing this body to endure. There is money to be made, not only in snuffing out life but in forcing it to persist. Like the child made creature in Ursula Le Guin's "The Ones Who Walk Away from Omelas," reduced to a wheezing husk of a no-longer-human being so that others might live harmoniously, those who should be or want to be dead are forced to keep up the illusion of life - exhale and inhale, defecate and urinate - so that their loved ones can be spared the guilt that capital imposes on them as it presents them with hospital bill after pharmaceutical bill, telling them that their desire to let go is a desire to spare their finances. They say there is no rest for the wicked, but it is the vulnerable, the discarded, those who are, paradoxically, framed as disposable who even in death are denied respite. Capital does rest, in the sense that it recedes into the background, and while it decides life and death, the affective burden for such decisions falls on people like my mother, who is not responsible but absorbs this responsibility into her body, into her psyche.

My mother's body breaks down as my grandmother's endures. She returns from her latest trip to Lebanon, ill. She takes longer than usual to recover from what should have been otherwise minor maladies. Her spirit and psyche, too, are particularly fragile. She is irritable, sensitive, paranoid. The guilt writhes and twists inside her like a demon. Why won't she die? Is it wrong to want her to die? Why is her soul still hanging on? What is she waiting for?

But she's not hanging on, is she? She's trapped here, tubes wrapped around her body like chains, IV drips nailing her down as though to a crucifix, making an unwilling sacrifice of her, the illusion of the selfless mother who, wanting to spare her children and grandchildren the pain of her demise, has chosen to suffer bodily pain so that they might have her presence near them for a little while longer. Even in death, the burden women bear. Even in death they must put others first. What screams does her feeding tube suffocate? What horror lies behind those gaping eyes? We hope for nothingness, for vegetativeness, 
for catatonia, in the face of more horrific possibilities, in the face of a consciousness beating desperately against the soundproof walls of the flesh.

What of the agency of the flesh? What of a body so desperate to die it attacks itself over and over, desperate to be released, to decay with pride, and not in the impersonal hospital, where its rotting is looked at with disgust, covered up, disinfected, purified - the sting, a punishment for daring to get out before it has been fully exploited. The sterility of evil.

As she waits for my grandmother to die, as she hopes for her respite to come soon while hating herself for an inability to determine whether her desire is selfless or selfish, my mother provides. Only the finest products - shampoos, creams. She plucks the hairs off my grandmother's chin, tidies up her hair - "your grandmother would hate to see herself this disheveled," she tells me. She grips her hand and tells her it's okay to leave. She begs her to let go, to end her suffering. She tells her the sacrifice isn't necessary, that the kids are and will be alright, and she can look down on them from above, that she can finally be with my grandfather, whom she loved so very much it made her body ache.

But, in the meantime, my mother can't acquiesce to the resistance of my grandmother's flesh, to seeing her in pain. She asks for no more tubes. She asks for a DNR. But her word, means nothing. She's just a daughter. Purchasing medicines and creams, massaging sore limbs, meeting with doctors, aren't enough to imbue her with authority. My grandmother's body continues to be exploited, as my mother's guilt is exploited, the two reproducing one another in a viscous cycle from which only capital benefits. Necropolitics is a word that gets thrown around so much it has started to feel like an empty signifier, but this is the politics of life and death in all its banality. 